\title{
Learning Innovation in Elementary School to Welcome the New Normal in Makassar City
}

\author{
Safaruddin ${ }^{1}$, Juanda Nawawi ${ }^{1}$, Nur Indrayati Nur Indar ${ }^{1}$, Muhammad Tang Abdullah ${ }^{1}$ \\ ${ }^{1}$ Department of Public Administration, Hasanuddin University, Indonesia
}

\begin{abstract}
The application of policy adaptive to the implementation of policies in the world of education will result in a control. The existence of a policy adaptive policy that is applied can measure $70 \%$ of the output generated from the policy. Therefore, policy adaptive makes policy implementation in the world of education more active to contribute in achieving the required tasks. This study aims to (1) describe and analyze educational policy settings. (2) Describe the design and implementation of education policies. (3) Knowing policy monitoring on the implementation of education policies. This research method uses a descriptive qualitative approach through case studies. Collecting data through observation, interviews, and documentation. Data analysis uses data reduction, data presentation, verification, and drawing conclusions. The results of this study found that policy adaptation in the implementation of education policies in the Covid 19 Era was applied with 3 indicators, namely (1) policy settings through 6 important points whose implementation was in accordance with the ability of the school. (2) the design and implementation of education policies is carried out through 9 points, namely SOP, School Task Force, Curriculum Design, Design of technical guidance and special training for educators, PTM scenarios for online learning, and coordination of schools with supervisors, task forces, health centers and the Committee for Policy Implementation Government. (3) policy monitoring on the implementation of education policies carried out through 6 stages.
\end{abstract}

Keywords: Innovation, Administration, Organization, Policy Adaptive

Received: October 12, 2021

Revised: November 21, 2021

Accepted: November 26, 2021

\section{Introduction}

Anxiety has hit Indonesia, over the Covid-19 pandemic, since the first cases emerged. Indonesia will have a hard time dealing with it, the effects of this pandemic will be very severe, the threat of health, economic and social crises will occur. The existence of government policies related to normalcy during the Covid-19 pandemic for the education sector itself is still holding online learning activities from the homes of each student based on previously issued circulars. The Ministry of Education and Culture in the circular dated May 18, 2020, suggested that services in the field of education during the 2019 COVID-19 pandemic occur through the provision of media and support for distance learning resources.

Especially in Makassar City, implementing policies in the field of education during the pandemic is not easy. The implementation of this policy in the field of education is based on a public administration management system. Management of matters related to public affairs to achieve good governance requires a reform in the institutional aspects and public management.

Reforms in institutions that include elements of government in the structure and infrastructure require improvement. In this case, institutional reform concerns the education sector, namely elements of the Education Council, Non-Governmental Organizations for example as implementing stakeholders and policy makers. For this reason, changes are needed in aspects of public sector management related to pandemic conditions, so an innovative or renewable 
(dynamic) government management model is needed that is relevant to current developments. So that the management change can run or manage the administrative bureaucracy running according to expectations.

As stated in the circular issued by the Head of Pusdatin Number: 1974/J1/PB/2020 to each educational institution related to the acceptance and implementation of education contained in 4 points, namely (1) support for online learning services for regions that do not support an online learning system, (2) the existence of a standard mechanism that is applied in the implementation of the available PPDB online services, referring to the regulation of the Minister of Education and Culture No. 44 of 2019 concerning PPDB, (3) the implementation of PPDB and infrastructure support that is managed independently in their respective regions, and (4) assistance activities carried out by the central team to prevent target errors in the implementation of online learning can be carried out, if these conditions are indeed possible. In this case the reform of policy implementation in the field of education to maximize its implementation requires an adaptive assistance.

Policy adaptive is the right approach to take when implementing education policies during a pandemic. Where for the implementation of the policy contains several factors that influence the implementation of a policy. The implementation of a policy can realize the expectations of policy makers and the institutions that implement the policy.

Arif Rohman (Erma, 2019a) argues, there are three factors that determine the occurrence of a failure or success in implementing a policy, namely: (1) factors in the formulation of policies taken by policy makers, related to clear editorial or not, the right objectives or not, understandable or not, can be interpreted or not, and not difficult to apply or not; (2) factors in implementing personnel, which are related to elements of education, commitment, loyalty, experience, motivation, performance, habits, self-confidence, and the ability to cooperate with actors from an implementer of the policy. Implementing personnel, including their respective linguistic, cultural, and ideological backgrounds, will greatly influence the collective working methods to carry out the mission of implementing a policy; (3) the factors in the implementing organization system, which are related to the system network, the hierarchical authority of each role, the distribution model in work, the style of an organizational leader, organizational SOPs, the objectives of each planned stage, a monitoring, and evaluation model to be carried out. chosen.

So based on the factors that influence the implementation of the policy, assistance is needed so that it runs according to expectations and is of course right on target. As stated by Van Meter and Van Horn (Elih, 2020) To start an idea related to the theory of implementing a policy, 6 variables are needed which include: (1) SOP and mission of the policy, (2) HR, (3) personal communication network, (4) organization and its validity activities, (5) character of policy implementers, (6) social and political background conditions. Grindle (2016) also argued, an application exposition can include tasks that are formed from a bond that occurs from two policy directions and can be realized in the results of government activities.

The implementation of public policy in practice cannot always be in line with planning, which is at the formulation stage of public policy, or between vision and reality. There is always a distortion between the things that are the mission of the vision and the things that are realized. Many factors can trigger distortions, such as resources that are needed, but not supported, while the implementation of public policies is something that cannot be delayed. Likewise, in terms of the quality of policy implementers who should have fulfilled the requirements as implementing actors, in reality they did not meet the criteria they should have. 
Grindle (2016) stated the three biggest obstacles that often exist in the implementation of public policies, among others: (1) there is no vertical cooperation from superiors and subordinates; (2) horizontal working relationship that is not synergistic; and (3) the problem of resistance to a change from the public or from the bureaucracy itself. In solving these obstacles, it is felt that it is necessary for a public policy implementer to have competencies that can adapt based on the conditions encountered in the field.

Different between public policy formulations that determine rationality requirements for a decision making, success in implementing public policy sometimes not only requires rationality, but also requires the ability of implementers to understand and respond to expectations that exist in society, as well as where the implementation of public policy will be. implemented.

Thus, the successful implementation of public policy requires a hierarchical and base-up approach simultaneously. The hierarchical approach that focuses on the support of the implementing unit in this case is the bureaucracy; standard implementation criteria; authority; and coordination. While the base-up approach focuses more on the strategy that will be used by the implementer when setting goals to be achieved in a public policy as a basis for understanding and implementing the public policy as a whole.

The success of the implementation of public policy is very dependent on the success of the identification of networks and cooperation carried out by the actors who are involved in the making and formulation of the public policy, where the final result of the policy is the actor who is the implementer of the public policy that has been made. Therefore, at the beginning of the public policy formulation stage, the implementing actors must know for sure who will have an interest in the policy; how the interaction of actors is formed; as well as what strategies are used to achieve these interests (Aishwary, 2017).

Acts as a liaison between this hierarchical and base-up approach, Sabatier (Rahimah, 2020) the importance of carrying out advocacy in public policy which is not only carried out at the formulation level but also at its implementation, and at the evaluation stage of the public policy. Advocacy in public policy includes the expression of partiality of an implementing actor towards certain values. The use of public policy advocacy in the implementation of public policy aims to bring about changes in the situation as desired through a strategy of ensuring that public policy makers are on the side of implementing advocacy, so that the aspirations of the community will be accommodated maximally .

The application of public policy is an activity of the public administration of an institution, which is intended as an exposition of the organization of activities by administrative units or units in the bureaucracy (Franklin, in Fatkuroji, 2016) in several levels of government that are vertical or at the level of public policy expositions (Mustopadidjaja, 2016).

As for the application of policy adaptive to the implementation of policies in the world of education will produce a control. For example, a policy that is implemented can measure $70 \%$ of the output produced by that policy. While other policy regulations can be installed to replace this policy and report about $90 \%$ of the output produced. A second regulatory policy could be produced in response to an adaptation policy that requires a minimum output of $90 \%$ (Aishwary, 2017). Therefore, policy adaptive makes policy implementation in the world of education more active to contribute in achieving the required tasks.

As explained earlier, policy adaptive is a process in which individuals, communities and countries try to cope with the consequences of climate change in accordance with the current changes in learning conditions due to a pandemic outbreak which in turn has an impact on 
limiting community movement space, including hampered learning implementation (Lisa, 2020). So it requires the making of new policies that demand the adjustment of conditions and implementation of these policies.

The application of policy adaptive in policies in the field of education is certainly a dynamic of the development of public administration science, the dynamics of changing developments, namely the application of different education implementation policies than usual, following changes in state conditions due to the pandemic that continues from 2019 to 2021 as well as happening in another country (Fatkuroji, 2016). Thus a brief description of the development of administrative science, especially public administration, which continues to develop following and strengthening its increasingly strategic position and role in the government process, including the implementation of policies in the field of education.

Based on the phenomenon of implementing policy adaptive in policies in the field of education from the perspective of public administration, it is felt that research needs to be done. What kind of dynamics appears in its implementation and how policy adaptive oversees the implementation of education policies in Makassar City.

\section{Methods}

This research uses a descriptive qualitative approach through case studies. Data collection was carried out from February to December 2020 through observation, interviews, and documentation. As for the informants include research informants are subjects who understand the information on the object of research as actors and other people who understand the object and focus of research. Then the research informants can be determined in two ways, namely: (1) key person or purposive sampling, and (2) snowball sampling. The main informant (key informant) is carried out if the researcher already has initial information about the research object and the second method with snowboling sampling is taken if researchers are completely unfamiliar with the object of research. In this study, key informants were determined purposively (deliberately) with the consideration that researchers already had initial information about the implementation of education policy implementation in Makassar City as the object under study. Research informants were determined, namely informants from elements of the Makassar City Government, namely the Mayor of Makassar, Head of the Education Office, Makassar City Education Council, Supervisors, Principals, Academics/Teachers. And those who come from non-government which include parents of students. Data analysis uses data reduction, data presentation, verification, and drawing conclusions.

\section{Results and Discussion}

\section{Policy settings applied to policy implementation in the field of education}

The transfer of face-to-face learning to online because of the pandemic conditions that require this to be done is a very appropriate policy. In the midst of a pandemic that is very susceptible to outbreaks, it is not possible to have direct physical contact, making the government have to take the right policy. The policy setting applied to the implementation of policies in the field of education during the pandemic through 6 decision points related to the continuity of learning and the education system in Makassar City is an implementation of policy adaptive.

The policy-making to change the education system into a special education system was stated by Ray and his friends (Wahab, 2015), through an illustration of the policy changes that occurred in the initial implementation of regional autonomy, there was a centralized transition 
to the era of decentralization. This happens through different topics where the transition from the face-to-face education system to an online-based education system.

The government's efforts to regulate policies taken as a result of the pandemic stem from the existence of policies that were born from adapting to the special conditions of the pandemic. Government policies in the field of education are demanded to be able to overcome the problem of the pandemic by keeping the education system running. Adapting to this pandemic condition, the Makassar city government implemented an education system based on the instructions of the ministry of education and culture in its implementation according to the conditions of the people of Makassar City.

The initial implementation of an online-based education system in Makassar City reaped many pros and cons. Where the character of the people of Makassar City who have a strong character tends to make government policies not run according to instructions. So that the level of Covidcases in Makassar City has significantly increased. Learning from the initial events of the pandemic, the Makassar City government then gave instructions to the Education Office to continue implementing the special education system by adapting the community environment through several learning implementation methods that adapt to the conditions of students, by not placing a burden on teachers and students, but containing values. strengthening the character that is formed in tandem with the Covid-19 condition.

The suitability of the learning carried out is based on Circular Letter Number 2 Years (Circular letter, 2020) concerning Prevention and Handling of Coronavirus in the Ministry of Education and Culture as well as Circular Letter Number 3 of 2020 concerning Prevention of Coronavirus in Education Units.

Furthermore, there is an adaptation of the special education system policy during the pandemic, other policies that are instructed by the next ministry are not necessarily conveyed to every school. Where the decision was made because it took into account the character of the people who were indifferent to the pandemic conditions which, if conveyed clearly about other policies such as the cancellation of the national exam (UN), adjustment of school exams, would lead to an even more fatal public response. In this case, the special learning system will be underestimated, which will ultimately have an impact on the decline in the quality of education for Makassar City students.

The Makassar City government's initial submission was based on environmental adaptation, namely the education system implemented through distance learning and an online approach to the student registration process according to Circular No. 4 of 2020 concerning the Implementation of Educational Policies in the Emergency Period for the Spread of Covid Disease (Coronavirus).

The delivery of the learning system then again reaped many obstacles, where complaints after complaints were accepted by teachers because during distance learning and online approaches, parents had difficulty facilitating students' learning. The implementation of this special education system has harmed students who come from underprivileged families and below. They are students who, even in ordinary conditions, already face barriers to accessing education. Now they need to face the additional barriers that inequalities have created to access technology infrastructure.

The implementation of this special education system, besides having an effect on students, also has an effect on teacher competence. The sudden change from the current face-to-face learning method in the classroom to distance learning carried out at home indicates the need for an increase in the teaching capacity of teachers. Several studies have shown that the information, 
communication, and technology (ICT) competencies of Indonesian masters are not evenly distributed throughout the region (Widodo and Riandi, 2013 quoted from Koh et al, 2018). The gap in fulfilling the unequal web access, the gap in master's qualifications, and the quality of education, as well as the lack of ICT skills are vulnerabilities in distance learning initiatives that occur in Makassar City.

Based on the existence of these gaps, both felt by students and teachers, the Makassar City government then issued a circular, in which each school was given the freedom to choose their online learning platform and this was subsequently contained in the decision of the Ministry of Education and Culture in 2020 (Kemendikbud, 2020).

The implementation of special education system policy settings that are applied shows little difference. If the Ministry of Education and Culture encourages knowledge sharing expositions by providing a trying free learning stage called "Rumah Belajar" and a stage for sharing between masters called the "Sharing Master Program", the Makassar City government gives teachers the freedom to innovate in learning by using applications that owned and can be used in delivering learning materials.

The Makassar city government held a meeting with all ranks of education policy makers within the Makassar City area to discuss the challenges of the world of education during the Infection Coronavirus pandemic. The discussion was carried out virtually by involving hundreds of education practitioners and inviting all parties to dare to create innovative educational methods as a solution to various problems that arise due to the outbreak.

This was stated by Marchau et al. (2010) termed the initial process of gathering policy requirements, objectives and constraints as the setting stage by conducting multi-stakeholder deliberation to generate discussion and understand policy objectives and requirements from multiple perspectives.

The policy taken by the Makassar City government is a policy adaptation that occurs when a formal decision or directive has been issued and the administrator is given the task of interpreting it and translating it into one or several policy proposals. The policy proposals instructed by the Ministry of Education and Culture are then implemented based on the environmental conditions in Makassar City broadly or more concretely, by studying the making of environmental conditions and considering the next steps to be implemented will produce the right decisions.

Where the adaptive policy itself will be produced with the Makassar City government clearly understanding the objectives of the policies taken. Whether by establishing distance learning or online will provide benefits and can overcome the learning system to keep it implemented and then this policy must then be analyzed for vulnerabilities and anticipatory actions must be determined for each policy implementer.

The efforts of the Makassar City government so far have shown seriousness in making policies related to the establishment of a learning system published with an applicable limit system. Where the Makassar City government really understands the character of society and its educational environment so that it provides limits as a means of providing brakes for students who do not study face-to-face with teachers while at the same time providing hope for teachers to be patient in undergoing online learning activities until the date the circular is in effect.

In addition to the freedom to innovate by using learning media freely, the Makassar City government also implements a system of cutting school fees by $30 \%$ to help people who experience significant economic conditions that have experienced a decline. The policy making 
was put forward by Walker et al (2016) that adaptive policy setting is the first step towards making policy that is capable of adapting in a dynamic and changing environment. The policies taken of course involve determining the objectives and requirements of the policy, identifying indicators that affect policy performance. Once the objectives and factors are determined, policymakers need to determine possible scenarios in which key factors affecting policy performance are affected and test different policy options to minimize the negative effects.

After the policy objectives have been determined by the Makassar City government, the next step is to identify the main factors that affect policy performance and plan for possible exceptions in the future. Migon et al. suggest a collaborative method for detecting possible exclusion policies and key policy factors through discussion among participants directly involved with policy where they discuss various policy exception scenarios based on experience.

What is meant by Migon in the special education system policy taken by the Makassar City government is policy making through collaboration between relevant stakeholders in the field of education including education offices and schools that take policies in implementing the education system based on real conditions of learning outside of the classroom. personal experience. This was also stated by Dekort and Booij (Samuel, 2015) provides a method for ranking these factors that can help policymakers design strategic choices among different measures while planning for possible exceptions and future uncertainties.

Although adaptive policy supports processes for dealing with expected and unforeseen situations, it is impossible for policy makers to take into account all possible scenarios and for this reason and therefore Walker et al. and Swanson and Bhadwal recommend having a contingency plan along with a specification of the conditions under which the entire policy should be reconsidered.

Different decision-making in the implementation of education policies in Makassar City also includes adaptive policies taken to deal with expected and unexpected situations in this case the COVID-19 pandemic, which is not where the policies taken also have shortcomings that may have detrimental effects in the future.

\section{Design and implementation of policies in education}

Once the policy requirements are defined during the preparation stage, policy makers can begin to design policies for thought. This phase can also be called the policy modeling phase. Various techniques have been developed on how to design an adaptive policy and the policy designer must make a decision to select the most appropriate design based on the needs of the setup stage. A review of the literature shows that event-driven policies that adapt to context, triggers and cues are the most commonly used (Marchau in Lisa, 2020).

The above shows that policy makers in implementing the special education system in Makassar City are designed based on needs in stages. Where the first stage of implementing the education system is designed to follow school learning SOPs combined with the application of health protocols in the implementation of learning. The policies implemented in Makassar City were driven by events that adjusted according to the context, the triggers and signs were the most commonly used (Marchau). Swanson et al. (Swanson et al) refer to techniques such as default policy adjustments and group them into two types automatic and semi-automatic. When policy conditions and anticipated events are well understood, fully automated policy adjustments are used. 
Furthermore, in its application there are two adjustment techniques contained therein. The first is the semi-technique, which is the awareness of students to always obey health protocols in participating in online and offline learning. The second technique is semi-automatic, which is shown by connecting students' understanding of pandemic conditions that require students to use masks to avoid transmission of the Covid-19 virus outbreak and the habit of washing hands.

The two implementation techniques described by Swanson et al refer to techniques such as default policy adjustments and categorize them into two types, automatic and semi-automatic. When policy conditions and anticipated events are well understood, fully automated policy adjustments are used. Some examples of fully automated policy adjustments include: (Malandrino et al.), who proposed a framework called MIMOSA that uses context awareness to change the behavior of policy rules in ubiquitous computing environments depending on user and device context. Similarly, (Lotlikar and Mohania) present a simple way to define an adaptable policy using a standard Action Condition Event model in which policies dynamically change themselves when some event is triggered.

On the other hand, when the anticipated events are not so well defined, semi-automatic policy adjustments are used. Karus et al. (Karus and Dumas) present a case study in which they used a combination of techniques to enforce policies semi-automatically.

\section{Policy monitoring on policy implementation in education}

Currently the education system is facing many problems, during the Coronavirus pandemic learning in Indonesia was shifted to distance education, but the lack of equipment, personnel, resources, and limited educational technology, as well as the skills and quality of the teachers were not sufficient (Erma, 2019b). The use of web/e-learning media has big obstacles, network connections and technical errors such as server down and mistakes hinder the success of learning (Elih, 2020). The implementation or implementation of challenging learning carried out in Makassar City is also guided by Permendikbud Number 19 of 2014 concerning the implementation of distance education at the elementary and secondary school levels. The other law used is Government Regulation Number 68 of 2005.

The online learning system utilizes the internet network system and learning models must be made and designed properly so that everything related to teaching and learning activities can be achieved optimally. In the implementation of online learning, what must be considered is the ability of teachers to provide teaching materials as well as the ability of students to receive subject matter because additional media is needed as an intermediary for the learning process. To be able to provide quality learning, the learning system must be made as attractive as possible so that students do not experience boredom in teaching and learning activities carried out online. A simple but quality system to make students more enthusiastic in participating in the learning process.

In the online learning system, teachers and students must interact with each other as well as possible so as not to appear that the teacher is only limited to giving assignments and training as their responsibilities and students must be required to complete the tasks given without any interaction and emotional closeness to the teacher. Teachers who are less responsive to student complaints during online learning will make students lazy in following the lessons given by the teacher. Online learning is also carried out so quickly that teachers must pay attention to the ability of students to receive learning.

Some of the principles that must be carried out by teachers in carrying out learning are (1) Attracting attention (acquiring consideration), things that arouse the interest of students by suggesting something new, strange, complex and contradictory. (2) Delivering learning

Copyright @ 2021, International Journal Papier Public Review, Under the license CC BY-SA 4.0 DOI: https://doi.org/10.47667/ijppr.v2i4.120 
objectives. Renew the abilities that must be mastered by students after participating in learning. (3) Remembering the concepts or principles that have been studied. Stimulates the memory of the knowledge that has been learned which is a prerequisite for further learning. (4) Deliver the lesson material that has been planned. (5) Provide study guidance. (6) Obtain the performance or appearance of students. Students are asked to show what they have learned or mastery of the material. (7) Give feedback. Tells how far the accuracy of students. (8) Assessing learning outcomes. (9) Strengthen retention and move learning.

Based on the nine points of reinforcement made by the teacher, it shows that the creativity of the teacher in providing material through the media is also needed as a factor that affects the interest of students in learning in this PJJ (Hatty, 2018). Problems in accepting the concepts and principles of the material will be difficult in $\mathrm{Pjj}$ learning without face to face, although educators can use learning media in learning expositions such as power points, hyperlinks, video instructional exercises, minimal circles (Albums) and interactive sight and sound based on CAI (Lisa, 2020).

The results obtained from the research conducted show that the online learning system implemented in Makassar City is running quite well although there are still shortcomings. Class teachers in providing material try to be as interesting as possible so that students do not experience boredom, follow established learning principles and concepts, guide students, especially students who are less able to absorb subject matter, there is evidence of the results of learning activities, the existence of interaction or discussion of each lesson, assessing learning outcomes and always increasing positive results in learning activities about students' understanding of the material being taught. In online learning activities, they use WhatsApp as an intermediary for learning, because this application is considered simpler and easier to use. Students can take part in learning well even though it is not done directly / face to face.

The learning carried out in Makassar City, the systems and concepts used are the same as the previous learning, only the material taught is more concise and simplified so that it is more practical and easy to deliver. In addition, the learning time is shorter so that students are not pressured and bored in online learning. Students are expected to develop more creativity at home after getting teaching materials delivered by class teachers. This is based on the fact that more time at home can be used by students in developing school lessons.

The learning process carried out during the pandemic is guided by the instructions issued by the Ministry of Education and Culture, but the implementation is carried out based on a circular issued by the Makassar City Education Office based on adaptive policies to harmonize the implementation of online learning during the pandemic so that it runs according to the community environment in Makassar City. . Thus, it shows that the learning system implemented at the Makassar City government's policy is really the result of adaptation to the City environment.

This was also stated by Walker et al (2016) divides the adaptive policy development process into two stages, the thinking stage and the policy implementation phase. The thinking phase mainly involves understanding the main requirements and components of the policy along with developing the rules that the policy instrument should act upon. The policy implementation phase on the other hand involves actions taken after the policy instrument has been put into practice.

\section{Conclusion}

Policy adaptation in the implementation of education policies in the Covid 19 Era is implemented with 3 indicators, namely (1) policy settings through 6 important points which 
are implemented in accordance with the ability of schools. (2) the design and implementation of education policies is carried out through 9 points, namely SOP, School Task Force, Curriculum Design, Design of technical guidance and special training for educators, PTM scenarios and online learning, and coordination of schools with supervisors, task forces, health centers and the Committee for Implementation Government policy. (3) policy monitoring on the implementation of education policies is carried out through 6 stages, namely: analyzing the situation, making several policy choices, evaluating policy choices, making decisions about education, planning policy implementation, assessing the impact of policy implementation, and determining the next policy cycle.

\section{References}

Aishwary, B., Amir Talaei-Khoei, Pradeep Ray. (2017). Adaptive policy framework. Journal of Network and Computer Applications, 36, 1261-1271.

Elih, Y. (2020). Implementasi Kebijakan Pendidikan (The Implementation of Educational Policies). Jurnal at-Tadbir: Media Hukum dan Pendidikan, 30(2).

Erma, F. (2019a). Kebijakan Pendidikan dalam Perspektf Peran Birokrasi dan Partisipasi Masyarakat. JIEMAN: Journal of Islamic Educational Management, 1(1).

Erma, F. (2019b). Kebijakan Pendidikan Dalam Perspektf Peran Birokrasi Dan Partisipasi Masyarakat. JIEMAN: Journal of Islamic Educational Management, 1(1).

Fatkuroji. (2016). Implementasi Kebijakan Pembelajaran Terpadu Dan Minat Pelanggan Pendidikan. Tarbawi, 2(2). https://www.neliti.com

Grindle, M. and T. S. (2016). Politics and Policy Implementation in The Third World. Princnton University Press.

Hatty, S. (2018). Persfektif Paradigma Baru Administrasi Publik dalam Menghadapi Pengaruh Globalisasi terhadap Penyelenggaraan Pemerintahan (Suatu Tinjauan dalam Pelayanan Publik).

Lisa, H. (2020). Public administrators' roles in the policy adaptation of transport directives: How knowledge is created and reproduced. Transport Policy, 98, 208-216.

Mustopadidjaja, A. (2016). Manajemen Proses Kebijakan Publi. Manajemen Proses Kebijakan Publik. Jakarta:

Rahimah, R., Juriah, N. ,. Karimah, N. ,. Hilmatunnisa, H. ,. \&. Sandra, T. (2020). The Problems and Solutions for Learning Activities during Covid-19 Pandemic Disruption in Hidayatul Insan Pondok School. Bulletin of Community Engagement, 1(1), 13-20.

Samuel. (2015). XML-based policy engineering framework for heterogeneous network management. Managing next generation networks and services, 244-253.

Surat Edaran, M. N. 4 T. 2020. (2020). Pelaksanaan Kebijakan Pendidikan dalam Masa Darurat Penyebaran corona Virus Desease (Covid-19).

Wahab, S. A. (2015). Analisis Kebijaksanaan: Dari Formulasi ke Implementasi Kebijaksanaan Negara (2 ed.). Bumi Aksara.

Walker, W., Rahman SA, Cave J. (2016). WE, Rahman SA, Cave J. European Journal of Operational Research. 